\title{
STUDI KORELASIONAL ANTARA MOTOR EDUCABILITY, FEEDBACK, DAN PERCAYA DIRI DENGAN KETERAMPILAN DRIBBLING INSTEP OF THE FOOT SISWA PUTRA EKSTRAKURIKULER SEPAKBOLA SMPN 29 JAKARTA TAHUN 2013
}

\author{
Nita Eka Aryanti \\ Program Studi D-III Ilmu Kepelatihan Olahraga, Akademi Olahraga Prestasi \\ Nasional
}

nita.eka.aryanti@akornas.ac.id

\begin{abstract}
ABSTRAK
Tujuan dari penelitian ini adalah untuk mengetahui hubungan antara motor educability $\left(\mathrm{X}_{1}\right)$, Feedback $\left(\mathrm{X}_{2}\right)$, dan percaya diri $\left(\mathrm{X}_{3}\right)$ dengan keterampilan Dribbling Instep of The Foot $(\mathrm{Y})$. Penelitian ini dilakukan di SMP 29 Jakarta, 14 s.d 16 Juni 2013, dengan menggunakan metode korelasional. Dengan sampel 35 siswa yang dipilih menggunakan teknik sampling total sampling.

Hasil penelitian adalah sebagai berikut. Pertama, adanya korelasi positif antara motor educability terhadap keterampilan Dribbling Instep of The Foot. Persamaan regresi linier yaitu $\widehat{Y}=9.73+0.81 X_{1}$. Koefisien korelasi 0,805 . Ini berarti kecenderungan motor educability terhadap keterampilan Dribbling Instep of The Foot adalah 65\%. Kedua, adanya korelasi positif antara feedback terhadap keterampilan Dribbling Instep of The Foot. Persamaan regresi linier yaitu $\hat{Y}=7.95+0.80 X_{3}$. Koefisien korelasi 0,653. Ini berarti kecenderungan feedback terhadap keterampilan keterampilan Dribbling Instep of The Foot adalah 43\%. Ketiga, adanya korelasi positif antara percaya diri terhadap keterampilan keterampilan Dribbling Instep of The Foot. Persamaan regresi linier yaitu $\hat{Y}=7.95+0.80 X_{3}$. Koefisien korelasi 0,801 . Ini berarti kecenderungan percaya diri terhadap keterampilan Dribbling Instep of The Foot adalah 64\%. Empat, adanya korelasi positif antara motor Educability, Feedback, dan percaya diri dengan keterampilan Dribbling Instep of The Foot. Persamaan regresi linier yaitu $\widehat{Y}=-0.35+$ $0.333 X_{1}+0.179 X_{2}+0.495 X_{3}$. koefisien korelasi 0,78 . Ini berarti kecenderungan motor Educability, Feedback, dan percaya diri bersama-sama terhadap keterampilan Dribbling Instep of The Foot adalah $61 \%$.
\end{abstract}

\section{Kata Kunci: Motor Educability, Feedback, Percaya Diri, Dribbling Instep Of The Foot}

\section{PENDAHULUAN}

Pendidikan jasmani merupakan proses pemenuhan kebutuhan individu yang meliputi aspek kognitif, afektif, dan psikomotor secara utuh, yang dapat terpenuhi melalui semua bentuk kegiatan jasmani. Pendidikan jasmani menjadi bagian integral dari suatu proses pendidikan secara keseluruhan. Proses pendidikan tersebut kegiatan jasmani dipilih untuk mengembangkan dan meningkatkan kemampuan organik, neuromuskular, interperatif, sosial, dan emosional. Bucher menjabarkan 5 tujuan yang hendak dicapai melalui pendidikan jasmani yaitu: (1) Organik, aspek ini terkait dengan masalah kemampuan siswa mengembangkan kekuatan otot, daya tahan cardiovaskuler, dan kelentukan; (2) Neuromuskuler, aspek ini terkait dengan masalah kemampuan siswa dalam mengembangkan keterampilan lokomotor, keterampilan nonlokomotor, dan bentuk-bentuk keterampilan dasar permainan, faktor-faktor gerak, keterampilan olahraga, dan keterampilan rekreasi; (3) Interpretif, aspek ini terkait dengan masalah kemampuan siswa untuk menyelidiki, menemukan, memperoleh pengetahuan dan membuat penilaian. Memahami peraturan permainan, mengukur keamanan, dan tata cara atau sopan santun. 
Menggunakan strategi dan teknik yang termasuk di dalam kegiatan organisasi. Mengetahui fungsi-fungsi tubuh dan hubungan dengan aktivitas fisik. Mengembangkan apresiasi untuk penampilan individu. Menggunakan penilaian yang dihubungkan dengan jarak, waktu, ruang, tenaga, kecepatan, dan aturan yang digunakan dalam pelaksanaan kegiatan, bola dan diri sendiri. Memahami faktor-faktor pertumbuhan dan perkembangan yang berhubungan dengan gerak. Berkemampuan memecahkan permasalahan dan berkembang melalui permainan; (4) Sosial, aspek ini terkait dengan masalah kemampuan siswa melakukan penilaian terhadap diri sendiri dan orang lain dengan menghubungkan individu untuk masyarakat dan lingkungannya. Kemampuan dalam membuat penilaian dalam suatu situasi kelompok. Belajar berkomunikasi dengan orang lain. Berkemampuan untuk merubah dan menilai ide-ide dalam kelompok. Pengembangan dari fase-fase sosial dari kepribadian, sikap, dan nilai-nilai agar menjadi anggota masyarakat yang berguna. Mengembangkan sifat-sifat kepribadian yang positif. Belajar untuk membangun waktu senggang yang bermanfaat. Mengembangkan sikap yang menggambarkan karakter moral yang baik; (5) Emosional, aspek ini terkait dengan masalah kemampuan siswa melakukan respon yang sehat terhadap kegiatan fisik melalui pemenuhan kebutuhan-kebutuhan dasar. Mengembangkan tindakan-tindakan positif dalam menonton dan keikutsertaan baik pada saat berhasil maupun kalah. Menyalurkan tekanan melalui kegiatankegiatan fisik yang bermanfaat. Mencari jalan keluar untuk ekspresi dan kreativitas untuk diri sendiri. Mewujudkan suatu pengalaman seni yang berasal dari kegiatankegiatan yang terkait. Berkemampuan untuk memiliki kegembiraan atau kesengsaraan. Program pendidikan jasmani dan unsurunsur yang terkandung dalam proses pembelajaran pendidikan jasmani sebagai salah satu bagian dari pencapaian tujuan pendidikan nasional yaitu, membentuk manusia yang beriman dan bertakwa kepada Tuhan Yang Maha Esa, berakhlak mulia, sehat, berilmu, cakap, kreatif, mandiri, dan menjadi warga negara yang demokratis serta bertanggung jawab.(UU.No.20,2003).

\section{KETERAMPILAN INSTEP OF THE FOOT \\ DRIBBLING}

Keterampilan berasal dari kata terampil yang berarti kemampuan atau kecakapan. Kecakapan dibutuhkan manusia dalam kehidupan sehari-hari, karena pada dasarnya manusia adalah mahkluk yang bergerak. Magil menjelaskan bahwa keterampilan merupakan suatu tindakan atau tugas yang dilakukan secara sengaja untuk mencapai suatu tujuan khusus. Keterampilan erat kaitannya dengan prilaku motorik. Keterampilan dalam perilaku motorik terdiri dari sejumlah respon motorik dan persepsi yang diperoleh melalui belajar.

Terdapat teori-teori pendukung belajar motorik. Teori stimulus-respons menggambarkan koneksi antara stimulus dan respons terjadi dalam keadaan seorang individu dalam hal ini peserta didik atau siswa melihat satu kaitan antara kedua elemen tersebut. Belajar sebagai proses pembentukan koneksi baru dan mengorganisasikannya ke dalam sistem dan mengembangkannya ke dalam pengetahuan, perilaku, dan kepribadian individu.

Teori yang dikembangkan sesuai teori stimulus-respons antara lain teori koneksionisme dari Thorndike. Penampilan motorik merupakan hasil kerja stimulusrespons dalam diri manusia. Dalam teori koneksionisme dari Thorndike menunjukkan bahwa stimulus berkaitan dengan respon tertentu. Pertautan (koneksi) antara stimulus dan respon akan terjadi secara otomatis. Sebagai perilaku atau aktivitas yang tidak dipelajari cenderung mendukung konteks tersebut. Selanjutnya sebagai stimulus dari lingkungan akan ditanggapi dengan respon tertentu yang hanya akan dikuasai melalui proses belajar atau latihan. Asumsi dasar Thorndike adalah asosiasi antara kesan yang diperoleh alat indera dan impuls untuk berbuat (respon). Asosiasi kedua bagian tersebut dikenal sebagai koneksi. Thorndike memandang bahwa penguasaan keterampilan memerlukan pertautan antara stimulus dan 
respon yang serasi. Thorndike membagi hukum asosiasi stimulus respon yang mempengaruhi belajar menjadi: (1) Low of readiness; (2) Low of exercise; (3) Low of effect.

Low of readiness atau hukum kesiapan menyatakan bahwa belajar akan berlangsung efektif bila siswa yang bersangkutan telah siap untuk menyesuaikan diri dengan stimulan dan telah siap untuk memberikan respons. Belajar akan lebih lancar jika materi yang disajikan cocok dengan kebutuhan individu. Sebaliknya individu akan terganggu dan tidak tertarik bila belum siap. Semakin individu matang mendekati kesiapan semakin memuaskan pula aktivitas yang dilakukan. Singer berpendapat bahwa keberhasilan dari suatu latihan tergantung kepada tingkat kesiapan siswa sebelum mengikuti kegiatan belajar dengan tingkat kesiapan yang memadai motivasi siswa akan timbul, keadaan ini sangat menguntungkan bagi kesiapan pelaksanaan pembelajaran.

Low of exercise atau hukum latihan menyatakan bahwa mengulang-ulang respon tertentu sampai beberapa kali akan memperkuat koneksi antara stimulus dan respons. Pertautan yang erat ini akan dikembangkan dan diperkuat melalui pengulangan yang memadai jumlahnya. Koneksi akan menjadi lemah bila latihan tidak diteruskan. Oleh sebap itu penguatan disini berarti respon tertentu akan diberikan jika situasi yang sama akan terjadi kembali. Inti dari hukum ini adalah pengulangan yang dilakukan melalui latihan akan membuat belajar semakin di kuasai. Dengan kata lain bahwa semakin banyak frekuensi pengulangan akan semakin mendekati penguasaan gerak.

Low of effect atau hukum pengaruh menunjukkan bahwa pengalaman yang menyenangkan dan memuaskan lebih menggiring seseorang untuk mengulangi lagi dari pada yang tidak menyenangkan. Seseorang cenderung mengganti pengalaman yang tidak menyenangkan dengan pengalaman yang lebih menyenangkan.

Dribbling salah satu bagian keterampilan dasar dalam permainan sepakbola dan merupakan materi yang diajarkan dalam pendidikan jasmani di sekolah dari tingkat sekolah dasar hingga sekolah tingkat atas. Dribbling atau menggiring dalam bahasa Indonesia adalah penguasaan bola dengan kaki saat bergerak di lapangan. Menggiring bola diartikan dengan gerakan lari menggunakan kaki mendorong bola agar bergulir terus menerus di atas tanah. Menggiring bola hanya dilakukan pada saat-saat yang menguntungkan saja, yaitu bebas dari lawan. Dribbling merupakan keterampilan dasar dalam sepakbola karena para pemain harus mampu menguasai bola saat sedang bergerak, berdiri, atau bersiap melakukan operan atau tembakan.

Dribbling menggunakan punggung kaki (instep of the foot) adalah salah satu cara menggiring bola yang sering diberikan sebagai bahan ajar dalam pendidikan jasmani di sekolah. Dribbling instep of the foot juga sering digunakan oleh seorang pemain sepakbola pada sebuah pertandingan sepakbola. Perkenaan bola di bagian punggung kaki lebih membuat bola dapat terkontrol dengan baik dan keseimbangan tubuh lebih stabil dikarenakan posisi kaki (pergelangan kaki sampai ujung kaki) searah dengan posisi tubuh. Menurut Remmy posisi dan sikap tubuh saat melakukan keterampilan Dribbling instep of the foot adalah sebagai berikut: 1) Mata melihat pada bola, 2) Kepala dan badan di atas bola, 3) Bola disentuh ke depan dengan punggung kaki (instep of the foot), 4) Ujung kaki yang menyentuh bola menghadap ke tanah, 5) Langkah-langkah dalam lari pendek-pendek, 6) Jarak bola tetap dalam penguasaan pemain, 7) Badan berada antara bola dan lawan.

\section{MOTOR EDUCABILITY}

Dalam belajar gerak terdapat dua kemampuan yang potensial banyak dipengaruhi faktor herediter atau keturunan, yaitu kemampuan gerak (Motor Ability) dan kemampuan belajar gerak (Motor Educability). Tingkat kemampuan gerak berkaitan dengan perolehan keterampilan, dan mempercepat proses perolehan keterampilan gerak.

Motor educability menurut Rusli Lutan adalah pengungkapan cepat 
lambatnya seseorang menguasai suatu keterampilan baru secara cermat. Ketika individu diberikan satu pembelajaran gerak yang belum pernah ia lakukan dan hasilnya setelah ia lakukan langsung dapat menguasai tanpa adanya kesulitan yang berarti, maka dapat dikatakan individu tersebut memiliki motor educabilitiy baik. Dalam suatu devinisi motor educability juga disebut kemampuan seseorang untuk belajar keterampilan motorik dengan baik dan mudah.

Tes motor educability oleh Brace, bertujuan untuk mengukur motor ability, terutama lebih menitik beratkan unsur kecakapan bawaan daripada kecakapan yang didapat. Sasaran tes adalah anak laki-laki dan anak perempuan dari usia Sekolah Dasar (SD) sampai dengan usia sekolah Lanjutan Atas (SLTA), usia 8 - 18 tahun, wanita sekolah tinggi. Tes terdiri dari 20 macam item, terbagi atas dua battery, setiap battery terdiri dari 10

macam.

Wahjoedi perpendapat pengertian motor educability yaitu kemampuan sesorang untuk menguasai gerakan-gerakan baru. Perkembangan selanjutnya, Mc.Cloy memperbaharui tes dari Brace untuk mengukur motor educability dengan nama IOWA - Brace Tes. Jenis-jenis tes yang dipilih harus memenuhi syarat sebagai berikut:

a. Persentasi pelaksanaan yang berhasil baik (naik dari tahun ke tahun dengan bertambahnya umur)

b. Masing-masing item memiliki korelasi yang rendah dengan kekuatan (Strength), body size, maturaty, postur.

c. Memiliki korelasi yang tinggi dengan nomor-nomor atletik.

Berdasarkan uraian di atas, secara umum tes motor educability yang dikembangkan oleh Brace secara umum dapat menilai kemampuan dasar sebagai berikut:

a) Control Prepacision, mendukung respon dengan hasil berupa gerakan yang dilakukan oleh sekumpulan otot atau segmen tubuh yang relatif besar dengan cepat dan cermat

b) Multilimb Coordination, Mendukung gerak koordinasi lebih dari satu anggota bagian tubuh, seperti dua tangan dan dua kaki.

c) Response Orientasi, mendukung gerak yang membutuhkan abilitas untuk memilih gerakan yang benar dalam situasi memilih waktu reaksi.

d) Reactin Time, mendukung gerakan reaksi pada obyek yang terjadi secepat mungkin karena adanya stimulus respon.

e) Speed of Arm Movement, Mendukung gerakan secepat mungkin untuk berpindah dari satu tempat ke tempat lain.

f) Rate Control atau Timing, mendukung gerakan anggota tubuh ynag disesuaikan dengan lingkungan dalam waktu yang cepat dan cermat.

g) Manual Dexterity, mendukung penanganan obyek yang besar terutama dengan lengan dan tangan.

h) Finger Dexterity, Mendukung penanganan obyek yang kecil terutama memerlukan gerakan jari.

i) Postural Discrimination, mendukung respon terhadap gerakan tubuh dalam keadaan tidak ada unsur penglihatan untuk melakukan penyesuaian badan secara cermat.

j) Respon Integration, mendukung gerakan tangan ketika menggabungkan dari beberapa respon yang ditimbulkan sehingga mempunya gerakan yang serasi.

k) Arm Hand Steadiness, mendukung gerak tangan sewaktu bergerak dari satu gerakan ke gerakan yang lain.

1) Wrist Fingger Speed, Mendukung gerakan jari-jari agar kecepatan yang ditimbulkan jari-jari semakin kuat.

m) Aiming, mendukung gerak ketepatan suatu titik tertentu.

n) Physical Prafinacy Stabilities, meliputi: kelenturan di tempat, kelenturan bergerak, kekuatan di tempat, kekuatan di pinggang, daya ledak, koordinasi anggota tubuh, keseimbangan, daya tahan fisik, fleksibel statis, fleksibel dinamis, kekuatan statis, kekuatan togok, kekuatan eksplosif, koordinasi badan, keseimbangan dan stamina.

Berdasarkan uraian tersebut di atas, maka yang dimaksud motor educability 
dalam penelitian ini adalah kemampuan belajar gerak yang potensial, yang menunjukkan kapasitas seseorang untuk mempelajari gerakan baru dalam waktu yang singkat dengan kualitas yang baik. Motor educability dianggap sebagai indikator intelegensi dalam belajar motorik. Diperkirakan bila seseorang dengan cepat menguasai suatu gerakan baru dengan kualitas baik, maka ia dapat dikatakan memiliki tingkat motor educabiliy yang tinggi, sebaliknya seseorang mungkin dapat dikatakan memiliki motor educability rendah apabila tidak mampu menguasai suatu gerakan baru dengan baik dan berkualitas.

\section{FEEDBACK}

Dalam suatu kegiatan proses belajar terjadi interaksi yang merupakan salah satu ciri menandakan terjadinya suatu proses belajar. Interaksi tersebut terjadi antara individu dengan individu atau individu dengan lingkungan. Interaksi adalah timbal balik atau saling mempengaruhi. Salah satu bentuk timbal balik adalah feedback (umpan balik). Dalam aktivitas pembelajaran pendidikan jasmani, guru menghargai siswa dan berkomunikasi secara efektif yang diwujudkan dengan terjadinya proses umpan balik atau feedback. Moston mengemukakan Feedback is generally defined as "telling people how they are doing." Feedback secara umum didefinisikan sebagai suatu tindakan memberi tahu seseorang tentang bagaimana ia melakukan kerja atau dalam hal ini memberitahukan tentang bagaimana seseorang melakukan suatu gerakan.

Feedback merupakan informasi sensoris yang dianggap sebagai hasil gerak mahkluk hidup yang bersangkutan. Informasi sensoris merupakan bagian dari kemampuan pemahan gerak. Feedback atau umpan balik adalah suatu proses dengan hasil atau akibat dari suatu respon untuk mengontrolnya. Hal ini sesuai dengan pendapat Rink "Feedback is sensory information that a person receives as a result of a response". Feedback sebagai sensori informasi yang diterima seseorang sebagai hasil meresponnya.
Adang Suherman mengatakan beberapa keuntungan umpan balik atau feedback antara lain sebagai berikut:

1. Mendorong siswa terus berlatih.proses pemberian umpan balik kepada siswa secara tidak langsung akan memberi tahu siswa bahwa latihannya selalu dilihat dan diperhatikan oleh guru.

2. Mencerminkan perilaku guru yang efektif. Dalam prosesnya, umpan balik hanya diperoleh apabila guru aktif selama kegiatan pembelajaran. Guru harus selalu memperhatikan siswa, bergerak untuk memantau dan mengamati aktivitas belajar yang dilakukan oleh setiap siswa disekitar tempat belajar atau berlatih.

3. Membantu siswa untuk menilai penampilan atau kemampuan yang tidak bisa dilihat dan dirasakannya sendiri.

4. Mendorong guru untuk menilai seberapa relevansi antara aspek-aspek pembelajaran dengan tingkat kemampuan siswa dalam menguasai tugas gerak atau bahan ajar seperti yang diinginkan oleh guru.

Umpan balik dapat dikirim ke peserta didik melalui beberapa model komunikasi: simbol, gerak tubuh, dan perilaku verbal. Simbol diwakili oleh gradasi huruf (A, B, C, dll), dengan angka (1-10), dengan persentase (0-100\%), dengan penghargaan (tempat pertama, tempat kedua, dll) atau dengan gambar. Simbolsimbol ini merupakan skala yang tindakan peserta didik individu yang dinilai. Gestures (juga disebut bahasa tubuh) yang diwakili oleh gerakan kepala, ekspresi wajah, gerakan tangan, dan konfigurasi jari. Perilaku verbal diwakili oleh kata-kata tertulis atau lisan dan frase, yang makna dan konotasi proyek yang dapat berubah ketika dibumbui dengan berbagai intonasi atau interpretasi budaya.

Menurut Moston ada empat bentuk feedback atau umpan balik antara lain : a) Value statements (pernyataan nilai,positif atau negatif), kriteria tunggal untuk umpan balik value statement (pernyataan nilai) adalah kehadiran sebuah kata (nilai) penilaian, baik positif atau negatif, b) Corrective statements (pernyataan koreksi), ada dua kriteria untuk mengidentifikasi 
pernyataan korektif yaitu ; (1) umpan balik ini mengacu pada kesalahan, (2) umpan balik ini mencakup identifikasi kesalahan dan koreksi, c) Neutral statements (pernyataan penengah), Semua pernyataan umpan balik netral dinyatakan dengan kriteria antara lain mereka secara faktual mengakui atau menggambarkan tindakan, mereka tidak menyatakan benar atau salah, d) Ambiguous statements (pernyataan ambigu), karakteristik umum untuk semua umpan balik ambigu adalah kesempatan untuk pernyataan dapat ditafsirkan atau disalahtafsirkan. Pernyataan ambigu tidak memproyeksikan nilai tertentu, mereka tidak mengidentifikasi kesalahan atau membuat koreksi jelas, dan tidak faktual mengakui peristiwa. Peserta didik tidak mampu untuk menerima nilai lebih spesifik dan umpan balik ambigu, karena mereka sering mendistorsi laporan ke umpan balik negatif. Fokus Saran atau masukan ambigu, bentuk umpan balik mencerminkan kurangnya kejelasan dan menyebabkan peserta didik untuk menafsirkan atau menebak makna guru, karena itu, fokus tidak spesifik tidak pasti. Karena asumsi dapat tidak dibuat tentang tingkat pemahaman yang sama, umpan balik ambigu tidak dapat diandalkan. Komentar-komentar ini, bagaimanapun, layak, jika tidak diinginkan, dalam situasi sosial di mana memproyeksikan nilai-nilai atau koreksi tidak pantas. Kelemahan ambiguitas menghasilkan rasa palsu dari pembelajar kepercayaan yang mengalami umpan balik sering ambigu mulai memikul tanggung jawab karena gagal untuk memahami konten. Peserta didik mulai meragukan kemampuan mereka sendiri untuk memahami, untuk berpikir, untuk menafsirkan. Umpan balik ambigu berlebihan akan meningkatkan perasaan kecewa.

\section{PERCAYA DIRI}

Percaya diri merupakan keyakinan dan sikap seseorang terhadap kemampuan pada dirinya sendiri dengan menerima secara apa adanya baik positif maupun negatif yang dibentuk dan dipelajari melalui proses belajar dengan tujuan untuk kebahagiaan dirinya. Dengan memiliki kepercayaan diri dapat mendorong semangat siswa mengikuti proses belajar. Percaya diri menggambarkan kondisi mental atau psikologis seseorang, dimana individu dapat mengevaluasi keseluruhan dari dirinya sehingga memberi keyakinan kuat pada kemampuan dirinya untuk melakukan tindakan dalam mencapai berbagai tujuan di dalam hidupnya. Dalam kehidupan seharihari percaya diri dapat menjadi senjata yang kuat oleh seorang individu dalam menghadapi tekanan yang dihadapi, sehingga individu tidak mudah putus asa bahkan depresi.

Percaya diri merupakan keyakinan dalam diri seseorang untuk dapat menangani segala sesuatu yang ada di hadapannya dengan tenang. Menurut Vealey dan knight, berdasarkan model sport confidence mengidentifikasi 3 komponen atau dimensi dalam sportconfidence, yaitu:

1) Latihan dan keterampilan fisik (Physical skills and Training).

Latihan dan keterampilan fisik merupakan tingkat keyakinan atau kepercayaan atlet bahwa dirinya memiliki kemampuan untuk menjalankan keterampilan fisik yang dibutuhkan guna menunjukkan penampilan yang sukses. Kepercayaan diri berkaitan erat dengan persepsi atlet mengenai kemampuan fisiknya. Penelitian Wilson dengan modifikasi SSCQ (Souces of Sport-Confidence Quetionere) menghasilkan bahwa rangking tertinggi yang menjadi sumber kepercayaan dari atlet yaitu kesiapannya secara fisik dan merasa menguasai keterampilan atau teknik yang dibutuhkan.

2) Efisiensi Kognitif (Cognitive Efficiency) Efisiensi Kognitif merupakan tingkat keyakinan atau kepercayaan atlet bahwa dirinya mampu memfokuskan diri, mampu memelihara konsentrasi dan membuat keputusan guna menunjukkan penampilan yang sukses. Dengan kata lain kerja kognitif atlet yang percaya diri harus menunjukkan kemampuan berpikir positif, bukan berpikir negatif.

3) Keuletan (Resiluence)

Keuletan merupakan tingkat keyakinan atau kepercayaan atlet bahwa dirinya 
mampu memfokuskan diri kembali setelah kegagalannya, mampu segera bangkit setelah penampilan yang buruk, mampu mengatasi keraguanmasalah dan penurunannya guna menunjukkan penampilan yang sukses. Keuletan juga dikaitkan dengan hasrat untuk mendapatkan hal-hal yang bersifat positif dan menghindari hal-hal yang bersifat negatif

Berdasarkan Berdasarkan beberapa pendapat di atas maka dapat diambil kesimpulan bahwa percaya diri adalah keyakinan seseorang terhadap kemampuan yang ada pada dirinya. Keyakinan tersebut adalah kekuatan dan dorongan untuk mencapai tujuan dan harapan yang dimiliki seseorang. Percaya diri merupakan bagian dari aspek afektif dalam pembelajaran pendidikan jasmani yang merupakan tujuan pembelajaran pendidikan jasmani dalam pembentukan karakter dan kepribadian siswa.

\section{METODE PENELITIAN}

Penelitian ini menggunakan pendekatan kuantitatif sehingga variabelvariabelnya dapat diukur dengan data yang terdiri dari angka-angka yang dapat dianalisis berdasarkan prosedur statistik. Metode yang digunakan yaitu metode survei untuk mengetahui informasi tentang variabel dari sekelompok objek. Dan teknik korelasional untuk mengidentifikasi hubungan prediktif

Populasi dalam penelitian ini adalah siswa putra ekstrakurikuler SMPN 29 Jakarta tahun ajaran 2012/2013 semester genap sejumlah 35 yang terdiri dari siswa putra kelas VII dan siswa putra kelas VIII. Dikarenakan populasi target yang tersedia sejumlah 35 orang siswa putra, maka teknik pengambilan sampel yang digunakan adalah sampling jenuh. Teknik sampling jenuh yaitu teknik penentuan sampel bila semua anggota populasi digunakan sebagai sampel. Data dianalisis dengan menggunakan teknik analisis sebagai berikut:

1) Pengujian persyaratan analisis, Teknik pengujian persyaratan analisis dalam penelitian yang bersifat korelasi mempunyai persyaratan pengujian yaitu uji normalitas data dan uji linearitas data,

2) Teknik pengujian hipotesis dalam penelitian. Teknik pengujian hipotesis penelitian digunakan analisisi regresi dan korelasi serta uji linear regresi

\section{HASIL PENELITIAN Deskripsi Data}

Deskripsi data hasil penelitian yang akan disajikan adalah mencakup empat variabel penelitian yaitu keterampilan dribbling ( $\mathrm{Y})$, motor educability $\left(\mathrm{X}_{1}\right)$, feedback $\left(\mathrm{X}_{2}\right)$, percaya diri $\left(\mathrm{X}_{4}\right)$ yang diperoleh dari sampel penelitian sebanyak 35 responden siswa ekstrakurikuler sepakbola SMPN 29 Jakarta. Setiap variabel diukur secara terpisah dengan menggunakan instrumen penelitian berupa hasil tes, pengamatan, dan kuesioner. Data yang dikumpulkan diolah dalam bentuk distribusi frekuensi, rerata, median, modus, simpangan baku, skor maksimum dan skor minimum. Deskripsi data setiap variabel penelitian tersebut adalah sebagai berikut:

\section{Keterampilan Dribbling (Y)}

Data keterampilan dribbling mempunyai rentang skor empiris antara 30 sampai dengan 68. Hasil perhitungan data diperoleh diperoleh rerata sebesar 50; simpangan baku sebesar 10; varians sebesar 100; median sebesar 50.8; dan modus sebesar 55.3.

\section{Motor Educability $\left(\mathrm{X}_{1}\right)$}

Data motor educability mempunyai rentang skor empiris antara 33 sampai dengan 69. Hasil perhitungan data diperoleh diperoleh rerata sebesar 50; simpangan baku sebesar 10; varians sebesar 100; median sebesar 52.3; dan modus sebesar 53.5.

\section{Feedback $\left(\mathrm{X}_{2}\right)$}

Data feedback mempunyai rentang skor empiris antara 31 sampai dengan 69. Hasil perhitungan data diperoleh diperoleh rerata sebesar 50; simpangan baku sebesar 10; varians sebesar 100; median sebesar 50.3; dan modus sebesar 49.1.

\section{Percaya Diri $\left(\mathrm{X}_{3}\right)$}

Data percaya diri mempunyai rentang skor empiris antara 32 sampai dengan 71. Hasil perhitungan data diperoleh diperoleh rerata sebesar 50; simpangan baku 
sebesar 10; varians sebesar 100; median sebesar 49; dan modus sebesar 45.5.

\section{Pengujian Hipotesa}

\section{Hubungan antara Motor Educability} dengan Keterampilan Dribbling.

Hipotesis pertama dalam penelitian ini adalah terdapat hubungan antara motor educability $\left(\mathrm{X}_{1}\right)$ dengan keterampilan dribbling (Y). Berdasarkan hasil analisis perhitungan regresi sederhana terhadap data keterampilan dribbling ( $\mathrm{Y})$ atas motor educability $\left(\mathrm{X}_{1}\right)$ dihasilkan koefisien arah regresi $\mathrm{b}$ sebesar 0.81 dan konstanta a sebesar 9.73. Dengan demikian diperoleh hubungan antara motor educability $\left(\mathrm{X}_{1}\right)$ dengan keterampilan dribbling (Y) yang dinyatakan oleh persamaan regresi $\widehat{Y}=$ $9.73+0.81 \mathrm{X}_{1}$. Untuk dapat digunakan sebagai keperluan prediksi, persamaan ini harus memenuhi syarat kelinieran dan keberartian (signifikansi). Pengujian signifikansi dan linieritas regresi dapat dilihat pada tabel 4.10 berikut.

Tabel 1. Hasil Analisis ANAVA untuk Persamaan Regresi Sederhana

$$
\widehat{\mathbf{Y}}=9.73+0.81 \mathrm{X}_{1} \text {. }
$$

\begin{tabular}{|c|c|c|c|c|c|c|}
\hline & & & & & & \\
\hline $\begin{array}{c}\text { Sumb } \\
\text { er }\end{array}$ & $\begin{array}{l}\text { D } \\
\text { k }\end{array}$ & Jml & Rjk & $\begin{array}{c}\text { F } \\
\text { Hit }\end{array}$ & 5 & $\begin{array}{l}\mathbf{0} \\
\mathbf{0} \\
\mathbf{1}\end{array}$ \\
\hline Total & $\begin{array}{l}3 \\
5\end{array}$ & $\begin{array}{c}9090 \\
0,00\end{array}$ & & \multirow{6}{*}{$\begin{array}{l}60,9 \\
3 * *\end{array}$} & \multirow{6}{*}{4} & \\
\hline $\begin{array}{l}\text { Regre } \\
\text { si a }\end{array}$ & 1 & $\begin{array}{l}8750 \\
0,00\end{array}$ & & & & \\
\hline $\begin{array}{l}\text { Regre } \\
\text { si b/a }\end{array}$ & 1 & $\begin{array}{c}2205 \\
, 52 \\
\end{array}$ & $\begin{array}{l}220 \\
5,52 \\
\end{array}$ & & & \\
\hline $\begin{array}{l}\text { Resid } \\
\mathrm{u}\end{array}$ & $\begin{array}{l}3 \\
3\end{array}$ & $\begin{array}{c}1194 \\
, 48\end{array}$ & $\begin{array}{c}36,2 \\
0\end{array}$ & & & 4 \\
\hline $\begin{array}{l}\text { Tuna } \\
\text { Cocok }\end{array}$ & 7 & $\begin{array}{c}354 \\
20\end{array}$ & $\begin{array}{c}50,6 \\
0\end{array}$ & & & \\
\hline Galat & $\begin{array}{l}2 \\
6 \\
\end{array}$ & $\begin{array}{c}840 \\
27\end{array}$ & $\begin{array}{c}32,3 \\
2\end{array}$ & & & \\
\hline
\end{tabular}

Dapat disimpulkan bahwa regresi $\widehat{\mathrm{Y}}=9.73+0.81 \mathrm{X}_{1} \quad$ adalah sangat signifikan dan berbentuk linier. Persamaan regresi ini mengandung makna bahwa setiap peningkatan satu satuan skor motor educability akan diikuti kenaikan skor keterampilan dribbling sebesar 0.81 satuan skor pada konstanta 9.73.

Hasil perhitungan atau derajat hubungan antara motor educability $\left(\mathrm{X}_{1}\right)$ dan keterampilan dribbling (Y) ditunjukkan oleh koefisien korelasi $\mathrm{r}_{\mathrm{y} 1}=0.805$. Uji signifikansi koefisien korelasi ini disajikan pada tabel berikut.

Tabel 2. Uji Signifikansi Koefisien

Korelasi Motor Educability $\left(\mathrm{X}_{1}\right)$ Dan Dribbling (Y)

\begin{tabular}{|c|c|c|c|c|c|}
\hline \multirow[b]{2}{*}{$\begin{array}{l}d \\
k\end{array}$} & \multirow[b]{2}{*}{$\begin{array}{l}\text { Koef } \\
\text { isien } \\
\text { Kor } \\
\text { elasi }\end{array}$} & \multirow{2}{*}{$\begin{array}{c}\text { Koefis } \\
\text { ien } \\
\text { Deter } \\
\text { minas } \\
\text { i } \\
\end{array}$} & \multirow[b]{2}{*}{$\begin{array}{c}\mathbf{t}_{\text {hitun }} \\
\mathrm{g}\end{array}$} & \multicolumn{2}{|c|}{$\mathbf{t}_{\text {tabel }}$} \\
\hline & & & & $\begin{array}{l}\alpha \\
=0.0\end{array}$ & $\begin{array}{l}\alpha \\
=0 .\end{array}$ \\
\hline 3 & & 84 & $\begin{array}{l}7.80 \\
6 * *\end{array}$ & 2.0 & 2.7 \\
\hline
\end{tabular}

** Koefisien korelasi sangat signifikan ${ }_{\left(t_{\text {hitung }}=7.806\right.}>\mathrm{t}_{\text {tabel }}=2.73$ pada $\alpha 0.01$.

Berdasarkan hasil uji signifikansi koefisien $\mathrm{t}_{\text {hitung }}=7.806>\mathrm{t}_{\text {tabel }}=2.73$ sehingga dapat disimpulkan bahwa koefisien korelasi antara motor educability $\left(\mathrm{X}_{1}\right)$ dan keterampilan dribbling (Y) sebesar 0.805 adalah sangat signifikan. Hal ini menunjukan terdapat hubungan positif antara motor educability $\left(\mathrm{X}_{1}\right)$ dengan keterampilan dribbling (Y). Hasil koefisien determinasi adalah $\mathrm{r}^{2}{ }_{\mathrm{y} 1}=0.649$ atau $65 \%$. Ini berarti bahwa $65 \%$ varians yang terjadi dalam kecenderungan hasil keterampilan dribbling dapat dijelaskan atau ditentukan oleh motor educability berdasarkan persamaan regresi $\widehat{Y}=9.73+0.81 \mathrm{X}_{1}$.

Kekuatan atau derajat hubungan antara variabel motor educability $\left(\mathrm{X}_{1}\right)$ dengan keterampilan dribbling (Y) dengan 'mengontrol pengaruh variabel feedback $\left(\mathrm{X}_{2}\right)$ didapat koefisien korelasi parsial sebesar $r_{\mathrm{y} 1.2}=0.627$. Dengan mengontrol variabel percaya diri $\left(\mathrm{X}_{3}\right)$ didapat koefisien korelasi parsial motor educability $\left(\mathrm{X}_{1}\right)$ dengan keterampilan dribbling $(\mathrm{Y}) \mathrm{r}_{\mathrm{y} 1.3}=$ 0.596. Dengan mengontrol variabel feedback $\left(\mathrm{X}_{2}\right)$ dan percaya diri $\left(\mathrm{X}_{3}\right)$ secara bersamaan didapat koefisien korelasi parsial feedback $\left(\mathrm{X}_{1}\right)$ dengan keterampilan dribbling $(\mathrm{Y}) \mathrm{r}_{\mathrm{y} 1.23}=0.349$.

Pengujian signifikansi korelasi parsial dengan mengontrol pengaruh 
variabel feedback $\left(\mathrm{X}_{2}\right)$ dan percaya diri $\left(\mathrm{X}_{3}\right)$ baik secara sendiri

maupun bersama-sama dapat dilihat pada tabel 3 berikut.

\section{Tabel 3. Uji Signifikansi Korelasi Parsial} $\mathrm{Y}$ dengan $\mathrm{X}_{1}$

\begin{tabular}{|c|c|c|c|c|c|c|}
\hline \multirow{2}{*}{$\begin{array}{c}\text { Su } \\
\text { mbe } \\
\mathbf{r}\end{array}$} & \multirow[b]{2}{*}{$\begin{array}{l}\mathbf{d} \\
\mathbf{k}\end{array}$} & \multirow[b]{2}{*}{$\begin{array}{c}\mathbf{J m} \\
\mathbf{l}\end{array}$} & \multirow{2}{*}{$\begin{array}{l}\text { Rata2 } \\
\text { Jk ( } \\
\text { Rjk ) }\end{array}$} & \multirow{2}{*}{$\begin{array}{c}\mathbf{F} \\
\mathbf{H i} \\
\mathbf{t}\end{array}$} & \multicolumn{2}{|c|}{ F Tabel } \\
\hline & & & & & $\begin{array}{l}\alpha \\
=\mathbf{0} .\end{array}$ & $\begin{array}{l}\alpha \\
=0\end{array}$ \\
\hline \multirow{4}{*}{$\begin{array}{l}\text { Tota } \\
1\end{array}$} & & 90 & & \multirow{12}{*}{$\begin{array}{c}24 \\
.5 \\
7 * \\
*\end{array}$} & \multirow{12}{*}{$\begin{array}{c}4.1 \\
4\end{array}$} & \multirow{12}{*}{$\begin{array}{c}7.4 \\
0\end{array}$} \\
\hline & 3 & 90 & & & & \\
\hline & 5 & 0,0 & & & & \\
\hline & & 0 & & & & \\
\hline & & 87 & & & & \\
\hline resi & 1 & 50 & & & & \\
\hline $\mathrm{a}$ & & 0,0 & & & & \\
\hline Reg & & $\frac{0}{14}$ & & & & \\
\hline resi & 1 & 51. & 1451.1 & & & \\
\hline $\mathrm{b} / \mathrm{a}$ & & 11 & 1 & & & \\
\hline \multirow{2}{*}{$\begin{array}{l}\text { Resi } \\
\mathrm{du}\end{array}$} & 3 & 19 & \multirow[b]{2}{*}{59.06} & & & \\
\hline & 3 & $\begin{array}{l}48 . \\
89\end{array}$ & & & & \\
\hline
\end{tabular}

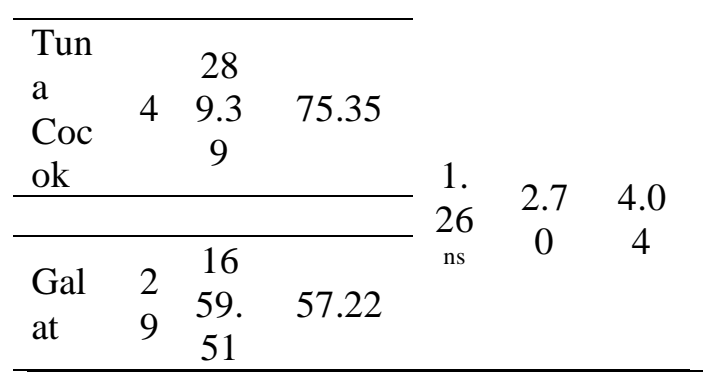

\begin{tabular}{|c|c|c|c|c|}
\hline \multirow{2}{*}{$\begin{array}{l}\text { D } \\
\mathbf{k}\end{array}$} & \multirow{2}{*}{$\begin{array}{c}\text { Koefisie } \\
\text { n } \\
\text { Korelasi }\end{array}$} & \multirow[b]{2}{*}{$\begin{array}{c}\mathbf{t}_{\text {hitun }} \\
\mathrm{g} \\
\end{array}$} & \multicolumn{2}{|c|}{$\mathbf{t}_{\text {tabel }}$} \\
\hline & & & $\begin{array}{l}\alpha \\
=0.05\end{array}$ & $\begin{array}{l}\alpha \\
=0.01\end{array}$ \\
\hline $\begin{array}{l}3 \\
2 \\
\end{array}$ & $\begin{array}{l}r_{y 1.2}= \\
0.627\end{array}$ & $\begin{array}{c}4.56 \\
* *\end{array}$ & 2.04 & 2.72 \\
\hline $\begin{array}{l}3 \\
2 \\
\end{array}$ & $\begin{array}{l}r_{y 1.3}= \\
0.596\end{array}$ & $\begin{array}{c}4.19 \\
* *\end{array}$ & 2.04 & 2.72 \\
\hline $\begin{array}{l}3 \\
1\end{array}$ & $\begin{array}{c}\mathrm{r}_{\mathrm{y} 1.23}= \\
0.349\end{array}$ & $\begin{array}{c}2.08 \\
*\end{array}$ & 2.03 & 2.70 \\
\hline
\end{tabular}

* Koefisien korelasi parsial signifikan $\left(t_{\text {hitung }}=>t_{\text {tabel }}\right.$ pada $\left.\alpha 0.05\right)$

* Koefisien korelasi parsial sangat signifikan ( $t_{\text {hitung }}>t_{\text {tabel }}$ pada $\left.\alpha 0.01\right)$

Berdasarkan uji signifikansi koefisien korelasi parsial tersebut di atas dapat disimpulkan bahwa: (1) dengan mengontrol pengaruh variabel feedback $\left(\mathrm{X}_{2}\right)$ tetap terdapat hubungan positif dan sangat signifikan antara motor educability $\left(\mathrm{X}_{1}\right)$ dengan keterampilan dribbling (Y); (2) dengan mengontrol variabel percaya diri $\left(\mathrm{X}_{3}\right)$ tetap terdapat hubungan positif dan sangat signifikan antara motor educability $\left(\mathrm{X}_{1}\right)$ dengan keterampilan dribbling $(\mathrm{Y})$; (3) dengan mengontrol variabel feedback $\left(\mathrm{X}_{2}\right)$ dan variabel percaya diri $\left(\mathrm{X}_{3}\right)$ secara bersama-sama tetap terdapat hubungan yang positif dan signifikan antara motor educability $\left(\mathrm{X}_{1}\right)$ dengan keterampilan dribbling (Y).

2. Hubungan antara Feedback dengan Keterampilan Dribbling.

Hipotesis kedua dalam penelitian ini adalah terdapat hubungan antara feedback $\left(\mathrm{X}_{2}\right)$ dengan keterampilan dribbling $(\mathrm{Y})$. Berdasarkan hasil analisis perhitungan regresi sederhana terhadap data keterampilan dribbling (Y) atas feedback $\left(\mathrm{X}_{2}\right)$ dihasilkan koefisien arah regresi $\mathrm{b}$ sebesar 0.65 dan konstanta a sebesar 17.34. Dengan demikian diperoleh hubungan antara motor educability $\left(\mathrm{X}_{1}\right)$ dengan keterampilan dribbling (Y) yang dinyatakan oleh persamaan regresi $\widehat{Y}=17.34+$ $0.65 \mathrm{X}_{2}$. Untuk dapat digunakan sebagai keperluan prediksi, persamaan ini harus memenuhi syarat kelinieran dan keberartian (signifikansi). Pengujian signifikansi dan linieritas regresi dapat dilihat pada tabel3 berikut.

Tabel 3. Hasil Analisis ANAVA Untuk Persamaan Regresi Sederhana $\widehat{\mathbf{Y}}=17.34+0.65 \mathrm{X}_{2}$.

Dapat disimpulkan bahwa regresi $\widehat{Y}=17.34+0.65 X_{2}$ adalah sangat signifikan dan berbentuk linier. Persamaan regresi ini mengandung makna bahwa setiap peningkatan satu satuan skor feedback akan diikuti kenaikan skor keterampilan dribbling sebesar 0.65 satuan skor pada konstanta 17.34 .

Hasil perhitungan atau derajat hubungan antara feedback $\left(\mathrm{X}_{2}\right)$ dan keterampilan dribbling (Y) ditunjukkan oleh koefisien korelasi $\mathrm{r}_{\mathrm{y} 2}=0.653$. Uji signifikansi koefisien korelasi ini disajikan pada tabel 4. 
Tabel 4. Uji Signifikansi Koefisien

Korelasi Motor Educability $\left(\mathbf{X}_{1}\right)$ Dan Keterampilan Dribbling (Y)

\begin{tabular}{|c|c|c|c|c|c|}
\hline \multirow[b]{2}{*}{$\begin{array}{l}d \\
k\end{array}$} & \multirow[b]{2}{*}{$\begin{array}{l}\text { Koef } \\
\text { isien } \\
\text { Kor } \\
\text { elasi }\end{array}$} & \multirow{2}{*}{$\begin{array}{l}\text { Koefis } \\
\text { ien } \\
\text { Deter } \\
\text { minas } \\
\text { i }\end{array}$} & \multirow[b]{2}{*}{$\begin{array}{c}\mathbf{t}_{\text {hitun }} \\
\mathrm{g}\end{array}$} & \multicolumn{2}{|c|}{$\mathbf{t}_{\text {tabel }}$} \\
\hline & & & & $\begin{array}{l}\alpha \\
=0.0\end{array}$ & $\begin{array}{l}\alpha \\
=0.0\end{array}$ \\
\hline 3 & & $+\angle 0$ & $7 * *$ & 2.04 & 2. \\
\hline
\end{tabular}

** Koefisien korelasi sangat signifikan $\left(\mathbf{t}_{\text {hitung }}=4.947>\mathbf{t}_{\text {tabel }}=\mathbf{2 . 7 3}\right.$ pada $\boldsymbol{\alpha} \mathbf{0 . 0 1}$.

Berdasarkan hasil uji signifikansi koefisien $\mathrm{t}_{\text {hitung }}=4.947>\mathrm{t}_{\text {tabel }}=2.73$ sehingga dapat disimpulkan bahwa koefisien korelasi antara feedback $\left(\mathrm{X}_{2}\right)$ dan keterampilan dribbling $(\mathrm{Y})$ sebesar 0.653 adalah sangat signifikan. Hal ini menunjukan terdapat hubungan positif antara feedback $\left(\mathrm{X}_{2}\right)$ dengan keterampilan dribbling (Y). Hasil koefisien determinasi adalah $\mathrm{r}^{2} \mathrm{y} 2=0.426$ atau $43 \%$. Ini berarti bahwa $43 \%$ varians yang terjadi dalam kecenderungan hasil keterampilan dribbling dapat dijelaskan atau ditentukan oleh feedback berdasarkan persamaan regresi $\widehat{\mathrm{Y}}=17.34+0.65 \mathrm{X}_{2}$.

Kekuatan atau derajat hubungan antara variabel feedback $\left(\mathrm{X}_{2}\right)$ dengan keterampilan dribbling (Y) dengan mengontrol pengaruh variabel motor educability $\left(\mathrm{X}_{1}\right)$ didapat koefisien korelasi parsial sebesar $r_{y 2.1}=0.101$. Dengan mengontrol variabel percaya diri $\left(\mathrm{X}_{3}\right)$ didapat koefisien korelasi parsial antara variabel feedback $\left(\mathrm{X}_{2}\right)$ dengan keterampilan dribbling $(\mathrm{Y}) \mathrm{r}_{\mathrm{y} 2.3}=0.554$. Selanjutnya dengan mengontrol variabel motor educability $\left(\mathrm{X}_{1}\right)$ dan percaya diri $\left(\mathrm{X}_{3}\right)$ secara bersamaan didapat koefisien korelasi parsial feedback $\left(\mathrm{X}_{2}\right)$ dengan keterampilan dribbling $(\mathrm{Y}) \mathrm{r}_{\mathrm{y} 2.13}=0.238$.

Pengujian signifikansi korelasi parsial dengan mengontrol pengaruh variabel motor educability $\left(\mathrm{X}_{1}\right)$ dan percaya diri $\left(X_{3}\right)$ baik secara sendiri maupun bersama-sama dapat dilihat pada tabel 10 . berikut.
Tabel 5. Uji Signifikansi Korelasi Parsial $\mathrm{Y}$ dengan $\mathrm{X}_{2}$

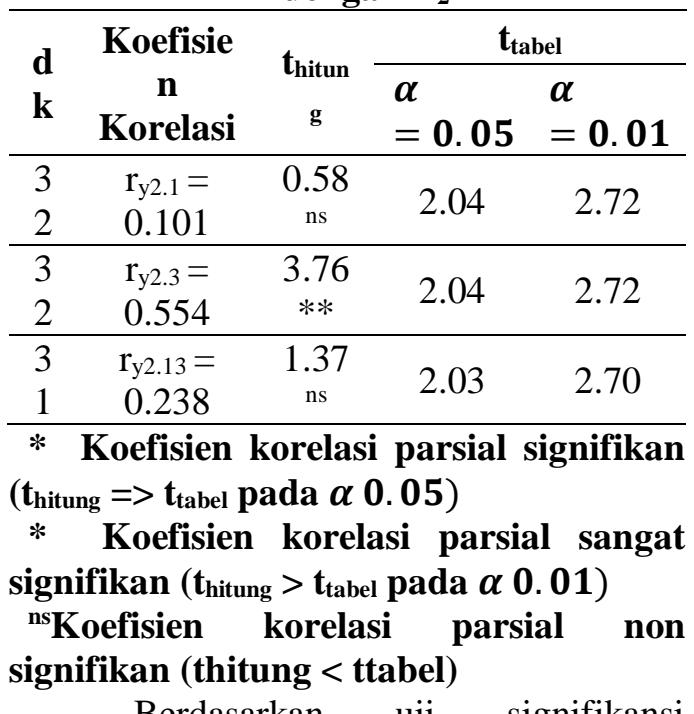

koefisien korelasi parsial tersebut di atas dapat disimpulkan bahwa: (1) dengan mengontrol pengaruh variabel motor educability $\left(\mathrm{X}_{1}\right)$ tidak terdapat hubungan positif dan signifikan antara feedback $\left(\mathrm{X}_{2}\right)$ dengan keterampilan dribbling (Y); (2) dengan mengontrol variabel percaya diri $\left(\mathrm{X}_{3}\right)$ tetap terdapat hubungan positif dan sangat signifikan antara feedback $\left(\mathrm{X}_{2}\right)$ dengan keterampilan dribbling (Y); (3) dengan mengontrol variabel motor educability $\left(\mathrm{X}_{1}\right)$ dan variabel percaya diri $\left(X_{3}\right)$ secara bersama-sama tidak terdapat hubungan yang positif dan signifikan antara feedback $\left(\mathrm{X}_{2}\right)$ dengan keterampilan dribbling (Y).

3. Hubungan antara Percaya Diri dengan Keterampilan Dribbling.

Hipotesis ketiga dalam penelitian ini adalah terdapat hubungan antara percaya diri $\left(\mathrm{X}_{3}\right)$ dengan keterampilan dribbling $(\mathrm{Y})$. Berdasarkan hasil analisis perhitungan regresi sederhana terhadap data keterampilan dribbling $(\mathrm{Y})$ atas percaya diri $\left(\mathrm{X}_{3}\right)$ dihasilkan koefisien arah regresi b sebesar 0.80 dan konstanta a sebesar 7.95. Dengan demikian diperoleh hubungan antara percaya diri $\left(\mathrm{X}_{3}\right)$ dengan keterampilan dribbling ( $\mathrm{Y})$ yang dinyatakan oleh persamaan regresi $\widehat{Y}=7.95+0.80 \mathrm{X}_{3}$. Untuk dapat digunakan sebagai keperluan prediksi, persamaan ini harus memenuhi syarat kelinieran dan keberartian (signifikansi). Pengujian signifikansi dan 
linieritas regresi dapat dilihat pada tabel 16 berikut.

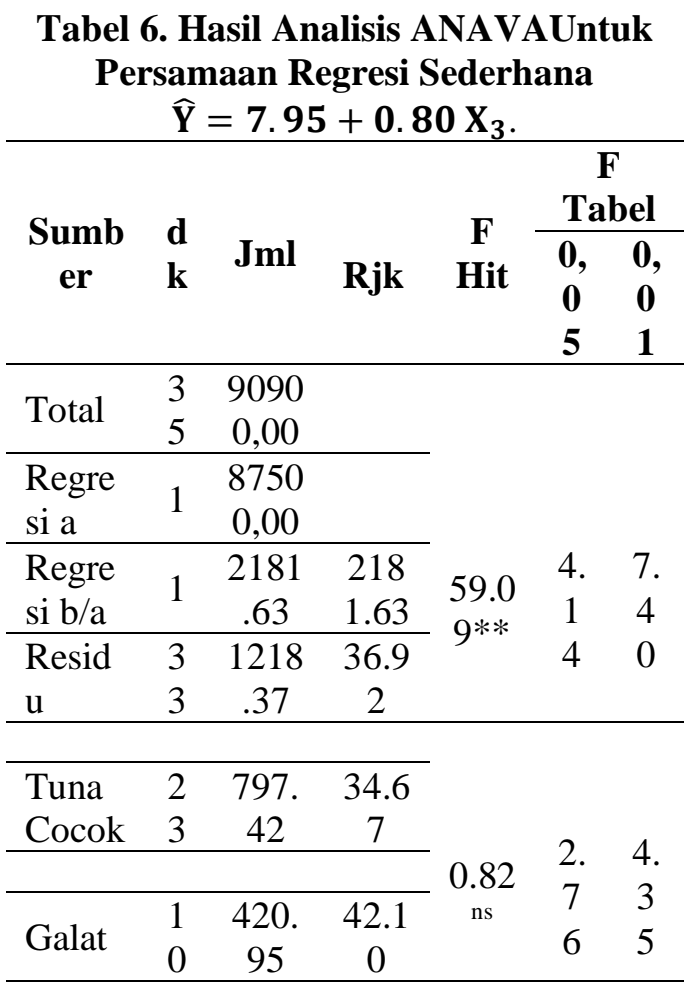

Dapat disimpulkan bahwa regresi $\widehat{\mathrm{Y}}=7.95+0.80 \mathrm{X}_{3} \quad$ adalah sangat signifikan dan berbentuk linier. Persamaan regresi ini mengandung makna bahwa setiap peningkatan satu satuan skor percaya diri akan diikuti kenaikan skor keterampilan dribbling sebesar 0.80satuan skor pada konstanta7.95.

Hasil perhitungan atau derajat hubungan antara percaya diri $\left(X_{3}\right)$ dan keterampilan dribbling (Y) ditunjukkan oleh koefisien korelasi $\mathrm{r}_{\mathrm{y} 3}=0.801$. Uji signifikansi koefisien korelasi ini disajikan pada tabel 7.

Tabel 7. Uji Signifikansi Koefisien Korelasi Percaya Diri $\left(\mathrm{X}_{1}\right)$ Dan Keterampilan Dribbling (Y)

\begin{tabular}{|c|c|c|c|c|c|}
\hline \multirow[b]{2}{*}{$\begin{array}{l}d \\
k\end{array}$} & \multirow[b]{2}{*}{$\begin{array}{l}\text { Koef } \\
\text { isien } \\
\text { Kor } \\
\text { elasi }\end{array}$} & \multirow{2}{*}{$\begin{array}{l}\text { Koefis } \\
\text { ien } \\
\text { Deter } \\
\text { minas } \\
\quad \text { i } \\
\end{array}$} & \multirow[b]{2}{*}{$\begin{array}{c}\mathbf{t}_{\text {hitu }} \\
\mathbf{n g}\end{array}$} & \multicolumn{2}{|c|}{$\mathbf{t}_{\text {tabel }}$} \\
\hline & & & & $\begin{array}{l}\alpha \\
=0.0 !\end{array}$ & $\begin{array}{l}\alpha \\
=0.0\end{array}$ \\
\hline 3 & $\begin{array}{c}.00 \\
1\end{array}$ & 2 & $\begin{array}{l}7.68 \\
7 * *\end{array}$ & 2.04 & 2.73 \\
\hline
\end{tabular}

** Koefisien korelasi sangat signifikan ( $_{\text {hitung }}=7.687>\mathbf{t}_{\text {tabel }}=\mathbf{2 . 7 3}$ pada $\alpha \mathbf{0 . 0 1}$.
Berdasarkan hasil uji signifikansi koefisien $\mathrm{t}_{\text {hitung }}=7.687>\mathrm{t}_{\text {tabel }}=2.73$ sehingga dapat disimpulkan bahwa koefisien korelasi antara percaya diri $\left(\mathrm{X}_{3}\right)$ dan keterampilan dribbling (Y) sebesar 0.801 adalah sangat signifikan. Hal ini menunjukan terdapat hubungan positif antara percaya diri $\left(\mathrm{X}_{3}\right)$ dengan keterampilan dribbling (Y). Hasil koefisien determinasi adalah $\mathrm{r}_{\mathrm{y} 3}^{2}=0.642$ atau $64 \%$. Ini berarti bahwa $64 \%$ varians yang terjadi dalam kecenderungan hasil keterampilan dribbling dapat dijelaskan atau ditentukan oleh percaya diri berdasarkan persamaan regresi $\widehat{Y}=7.95+0.80 \mathrm{X}_{3}$.

Kekuatan atau derajat hubungan antara variabel percaya diri $\left(\mathrm{X}_{3}\right)$ dengan keterampilan dribbling (Y) dengan mengontrol pengaruh variabel motor educability $\left(\mathrm{X}_{1}\right)$ didapat koefisien korelasi parsial sebesar $r_{y 3.1}=0.585$. Dengan mengontrol variabel feedback $\left(\mathrm{X}_{2}\right)$ didapat koefisien korelasi parsial percaya diri $\left(\mathrm{X}_{3}\right)$ dengan keterampilan dribbling $(\mathrm{Y}) \mathrm{r}_{\mathrm{y} 3.2}=$ 0.753 . Dengan mengontrol variabel motor educability $\left(\mathrm{X}_{1}\right)$ dan variabel feedback $\left(\mathrm{X}_{2}\right)$ secara bersamaan didapat koefisien korelasi parsial percaya diri $\left(\mathrm{X}_{3}\right)$ dengan keterampilan dribbling $(\mathrm{Y}) \mathrm{r}_{\mathrm{y} 3.12}=0.611$.

Pengujian signifikansi korelasi parsial dengan mengontrol pengaruh variabel motor educability $\left(\mathrm{X}_{1}\right)$ dan feedback $\left(\mathrm{X}_{2}\right)$ baik secara sendiri maupun bersamasama dapat dilihat pada tabel 4.18 berikut.

Tabel 8. Uji Signifikansi Korelasi Parsial $\mathrm{Y}$ dengan $\mathrm{X}_{3}$

\begin{tabular}{|c|c|c|c|c|}
\hline \multirow{2}{*}{\multicolumn{2}{|c|}{$\begin{array}{cc} & \text { Koefisie } \\
\text { D } & \mathbf{n} \\
\mathbf{k} & \text { Korelas } \\
& \mathbf{i} \\
\end{array}$}} & \multirow[b]{2}{*}{$\mathbf{t}_{\text {hitung }}$} & \multicolumn{2}{|c|}{$\mathbf{t}_{\text {tabel }}$} \\
\hline & & & $\begin{array}{l}\alpha \\
=0.05\end{array}$ & $\begin{array}{l}\alpha \\
=0.01\end{array}$ \\
\hline $\begin{array}{l}3 \\
2 \\
\end{array}$ & $\begin{array}{l}r_{\mathrm{y} 3.1}= \\
0.585\end{array}$ & $\begin{array}{c}4.078 \\
* *\end{array}$ & 2.04 & 2.72 \\
\hline $\begin{array}{l}3 \\
2 \\
\end{array}$ & $\begin{array}{l}\mathrm{r}_{\mathrm{y} 3.2}= \\
0.753\end{array}$ & $\begin{array}{c}6.469 \\
* *\end{array}$ & 2.04 & 2.72 \\
\hline $\begin{array}{l}3 \\
1 \\
\end{array}$ & $\begin{array}{c}r_{y 3.12}= \\
0.611\end{array}$ & $\begin{array}{c}4.293 \\
* \\
\end{array}$ & 2.03 & 2.70 \\
\hline & $\begin{array}{l}\text { efisien } \\
=>t_{\text {tabel }} \\
\text { oefisien } \\
\text { kan }\left(t_{\text {hitu }}\right.\end{array}$ & $\begin{array}{l}\text { korel } \\
>t_{t a l}\end{array}$ & $\begin{array}{l}\text { arsial } \\
\text { 5) }\end{array}$ & ifikan \\
\hline
\end{tabular}


Berdasarkan uji signifikansi koefisien korelasi parsial tersebut di atas dapat disimpulkan bahwa: (1) dengan mengontrol pengaruh variabel motor educability $\left(\mathrm{X}_{1}\right)$ tetap terdapat hubungan positif dan sangat signifikan antara percaya diri $\left(\mathrm{X}_{3}\right)$ dengan keterampilan dribbling $(\mathrm{Y})$; (2) dengan mengontrol variabel feedback $\left(\mathrm{X}_{2}\right)$ tetap terdapat hubungan positif dan sangat signifikan antara percaya diri $\left(\mathrm{X}_{3}\right)$ dengan keterampilan dribbling (Y); (3) dengan mengontrol variabel motor educability $\left(\mathrm{X}_{1}\right)$ dan variabel feedback $\left(\mathrm{X}_{2}\right)$ secara bersama-sama tetap terdapat hubungan yang positif dan signifikan antara percaya diri $\left(\mathrm{X}_{3}\right)$ dengan keterampilan dribbling (Y).

4. Hubungan Positif antara Motor Educability $\left(\mathbf{X}_{1}\right)$, Feedback $\left(\mathbf{X}_{2}\right)$, Percaya Diri $\left(\mathbf{X}_{3}\right)$ Bersama-Sama Dengan Keterampilan Dribbling (Y).

Berdasarkan hasil regresi jamak antara motor educability $\left(\mathrm{X}_{1}\right)$, feedback $\left(\mathrm{X}_{2}\right)$, percaya diri $\left(\mathrm{X}_{3}\right)$ bersama-sama dengan keterampilan dribbling $(\mathrm{Y})$ diketahui bahwa $\mathrm{b} 1=0.333 ; \mathrm{b} 2=0.179 ; \mathrm{b} 3=0.495$ dengan besar konstanta $\mathrm{a}=-0.35$. Dengan demikian bentuk hubungan antara motor educability $\left(\mathrm{X}_{1}\right)$, feedback $\left(\mathrm{X}_{2}\right)$, percaya diri $\left(X_{3}\right)$ bersama-sama dengan keterampilan dribbling (Y) ditunjukkan dalam persamaan regresi $\widehat{Y}=-0.35+0.333 X_{1}+$

$0.179 X_{2}+0.495 X_{3}$. Setelah itu dilakukan penghitungan ANAVA untuk menguji signifikansi regresi, diperoleh kesimpulan bahwa model persamaan regresi tersebut ialah sangat signifikan.

Selanjutnya, berdasarkan hasil penghitungan diperoleh koefisien korelasi jamak antara motor educability $\left(\mathrm{X}_{1}\right)$, feedback $\left(\mathrm{X}_{2}\right)$, percaya diri $\left(\mathrm{X}_{3}\right)$ bersamasama dengan keterampilan dribbling (Y) ditunjukkan dengan koefisien korelasi Ry. 123 $=0.78$. Koefisien korelasi ini setelah dilakukan perhitungan uji signifikansi diperoleh nilai $\mathrm{F}_{\text {hitung }}=16.16$ dan $\mathrm{F}_{\text {tabel }}$ pada taraf nyata $\alpha 0.05=2.90$, sedangkan pada taraf nyata $\alpha 0.01=4.50 ; \mathrm{F}_{\text {hitung }}>\mathrm{F}_{\text {tabel }}$ pada taraf nyata 0.01 . dengan demikian korelasi jamak antara motor educability $\left(\mathrm{X}_{1}\right)$, feedback $\left(\mathrm{X}_{2}\right)$, percaya diri $\left(\mathrm{X}_{3}\right)$ bersama- sama dengan keterampilan dribbling adalah sangat signifikan.

Dengan demikian terdapat hubungan positif antara motor educability, feedback, percaya diri bersama-sama dengan keterampilan dribbling artinya semakin tinggi motor educabilitt,semakin tinggi feedback, dan semakin tinggi percaya diri maka semakin tinggi pula keterampilan dribbling siswa ekstra kurikuler sepakbola SMP 29 Jakarta. Dengan begitu hipotesis keempat terbukti.

Apabila ditemukan koefisien korelasi sebesar $\mathrm{Ry}_{\cdot 123}=0.78$, maka koefisien determinasinya ialah $\mathrm{R}^{2} \mathrm{y} \cdot 123=(0.78)^{2}=0.61$ atau $61 \%$. Ini berarti bahwa $61 \%$ keterampilan dribbling yang dimiliki siswa dapat ditentukan oleh motor educability, feedback, dan percaya diri secara bersamasama, sisanya sebesar 39\%dijelaskan oleh faktor lainnya.

Dari pembahasan uji hipotesis pertama, hipotesis kedua,dan hipotesis ketiga, dapat dirangkum analisis korelasi dengan faktor-faktor lain dikontrol dapat diperingkatkan seperti tertera dalam tabel 4.19 berikut.

Tabel 9. Peringkat Kekuatan Hubungan antara Variabel $X_{1}$ dengan Mengontrol Variabel $X_{2}$ dan $X_{3}$ antara Variabel $X_{2}$ dengan Mengontrol Variabel $X_{1}$ dan $X_{3}$ antara Variabel $X_{3}$ dengan Mengontrol Variabel $X_{1}$ dan $X_{2}$ Koefisien Peringkat

Korelasi Parsial

\begin{tabular}{cc}
\hline $\mathrm{ry}_{3.12}=0.611$ & Pertama \\
\hline $\mathrm{ry}_{1.23}=0.349$ & Kedua \\
\hline $\mathrm{ry}_{2.13}=0.238$ & Ketiga \\
\hline Dari informasi & yang tertera pada
\end{tabular}
tabel di atas dapat disimpulkan bahwa peringkat kekuatan hubungan masingmasing variabel bebas terhadap variabel terikat menunjukkan variabel percaya diri $\left(\mathrm{X}_{3}\right)$ dengan $\mathrm{ry}_{3.12}=0.611$ menempati peringkat pertama; variabel motor educability $\left(\mathrm{X}_{1}\right)$ dengan $\mathrm{ry}_{1.23}=0.349$ menempati peringkat kedua; dan variabel feedback $\left(\mathrm{X}_{2}\right)$ dengan $\mathrm{ry}_{2.13}=0.238$ menempati peringkat ketiga, dalam hubungannya dengan keterampilan dribbling. 


\section{KESIMPULAN}

Berdasarkan penelitian yang telah diuraikan di atas, maka dapat diambil kesimpulan:

1. Berdasarkan hasil pengujian hipotesis pertama menunjukkan bahwa terdapat hubungan yang signifikan antara motor educability (X1) dengan keterampilan dribbling (Y) siswa ekstrakurikuler sepakbola SMPN 29 Jakarta dengan menunjukkan model persamaan regresi $\widehat{\mathrm{Y}}=9.73+0.81 \mathrm{X}_{1}$. Melalui analisis varians diperoleh koefisien thitung $=7.806$ $>\mathrm{t}_{\text {tabel }}=2.73$ sehingga dapat disimpulkan bahwa koefisien korelasi antara motor educability $\left(\mathrm{X}_{1}\right)$ dan keterampilan dribbling (Y) sebesar 0.805 adalah sangat signifikan. Hal ini menunjukan terdapat hubungan positif antara motor educability $\left(\mathrm{X}_{1}\right)$ dengan keterampilan dribbling (Y). Hasil koefisien determinasi adalah $\mathrm{r}^{2}{ }_{\mathrm{y} 1}=0.649$ atau $65 \%$. Ini berarti bahwa $65 \%$ varians yang terjadi dalam kecenderungan hasil keterampilan dribbling dapat dijelaskan atau ditentukan oleh motor educability.

2. Berdasarkan hasil pengujian hipotesis kedua menunjukkan bahwa terdapat hubungan yang signifikan antara feedback $\left(\mathrm{X}_{2}\right)$ dengan keterampilan dribbling (Y) siswa ekstrakurikuler sepakbola SMPN 29 Jakarta dengan menunjukkan model persamaan regresi $\widehat{\mathrm{Y}}=17.34+0.65 \mathrm{X}_{2}$. Melalui analisis varians diperoleh koefisien $t_{\text {hitung }}=4.947$ $>\mathrm{t}_{\text {tabel }}=2.73$ sehingga dapat disimpulkan bahwa koefisien korelasi antara feedback $\left(\mathrm{X}_{2}\right)$ dan keterampilan dribbling $(\mathrm{Y})$ sebesar 0.653 adalah sangat signifikan. Hal ini menunjukan terdapat hubungan positif antara feedback $\left(\mathrm{X}_{2}\right)$ dengan keterampilan dribbling (Y). Hasil koefisien determinasi adalah $\mathrm{r}^{2} \mathrm{y} 2=0.426$ atau $43 \%$. Ini berarti bahwa $43 \%$ varians yang terjadi dalam kecenderungan hasil keterampilan dribbling dapat dijelaskan atau ditentukan oleh feedback.

3. Berdasarkan hasil pengujian hipotesis ketiga menunjukkan bahwa terdapat hubungan yang signifikan antara percaya diri $\left(\mathrm{X}_{3}\right)$ dengan keterampilan dribbling (Y) siswa ekstrakurikuler sepakbola
SMPN 29 Jakarta dengan menunjukkan model persamaan regresi $\widehat{Y}=7.95+$ $0.80 \mathrm{X}_{3}$. Melalui analisis varians diperoleh koefisien koefisien $t_{\text {hitung }}=$ $7.687>\mathrm{t}_{\text {tabel }}=2.73$ sehingga dapat disimpulkan bahwa koefisien korelasi antara percaya diri $\left(\mathrm{X}_{3}\right)$ dan keterampilan dribbling (Y) sebesar 0.801 adalah sangat signifikan. Hal ini menunjukan terdapat hubungan positif antara percaya diri $\left(\mathrm{X}_{3}\right)$ dengan keterampilan dribbling $(\mathrm{Y})$. Hasil koefisien determinasi adalah $\mathrm{r}_{\mathrm{y} 3}^{2}=0.642$ atau $64 \%$. Ini berarti bahwa $64 \%$ varians yang terjadi dalam kecenderungan hasil keterampilan dribbling dapat dijelaskan atau ditentukan oleh percaya diri.

4. Hasil penelitian yang menyebutkan bahwa terdapat hubungan bentuk hubungan antara motor educability $\left(\mathrm{X}_{1}\right)$, feedback $\left(\mathrm{X}_{2}\right)$, percaya diri $\left(\mathrm{X}_{3}\right)$ bersamasama dengan keterampilan dribbling $(\mathrm{Y})$ menunjukkan model persamaan regresi ganda $\widehat{\mathrm{Y}}=-0.35+0.333 X_{1}+$ $0.179 X_{2}+0.495 X_{3}$. Melalui analisis koefisien korelasi ini setelah dilakukan perhitungan uji signifikansi diperoleh $\mathrm{F}_{\text {hitung }}=16.16$ dan $\mathrm{F}_{\text {tabel }}$ pada taraf nyata $\alpha 0.05=2.90$, sedangkan pada taraf nyata $\alpha 0.01=4.50 ; \mathrm{F}_{\text {hitung }}>\mathrm{F}_{\text {tabel }}$ pada taraf nyata 0.01 . dengan demikian korelasi jamak antara motor educability $\left(\mathrm{X}_{1}\right)$, feedback $\left(\mathrm{X}_{2}\right)$, percaya diri $\left(\mathrm{X}_{3}\right)$ bersama-sama dengan keterampilan dribbling (Y) adalah sangat signifikan.Berdasarkan persamaan koefisien korelasi sebesar Ry.123 $=0.78$, maka koefisien determinasinya ialah $\mathrm{R}^{2} \mathrm{y} \cdot 123=(0.78)^{2}=0.61$ atau $61 \%$. Ini berarti bahwa $61 \%$ keterampilan dribbling yang dimiliki siswa dapat ditentukan oleh motor educability, feedback, dan percaya diri secara bersama-sama, sisanya sebesar $39 \%$ dijelaskan oleh faktor lainnya.

\section{SARAN}

Berdasarkan uraian pada kesimpulan dan hasil penelitian, berikut akan dikemukakan beberapa saran untuk meningkatkan keterampilan dribbling pada siswa sebagai berikut: 
1. Pelatih dan guru pendidikan jasmani dalam menerapkan pembelajara keterampilan dribbling ataupun pengembangan gerak spesialisasi lainnya menekankan proses belajar gerak dasar yang benar dalam hal ini dikembangkan dalam pelaksanaan keterampilan dribbling.

2. Metode yang digunakan dalam suatu proses belajar gerak diharapkan mampu mengeksplor kemampuan yang dimiliki siswa.

3. Karena penelitian ini sifatnya terbatas maka disarankan bagi peneliti lainnya agar dilakukan penelitian yang lain dan mengembangkannya atau meneliti dengan variabel lain yang berhubugan dengan keterampilan sepakbola atau pengembangan gerak yang lain.

\section{DAFTAR PUSTAKA}

Burns,Tim. Holistic Futsal a Total Mindbody, Spirit Approach. United Kingdom: Lightning Source UK Itd, 2003.

Coker, Cheryl A. Motor Learning And Control For Practitioners. New York: Mc Graw Hill, 2004

Chyzowych, Walter. The Official Soccer Book of The United States Soccer Federation. United States of America: Rand McNally \& Company, 1978.

Clarke, H. Harrison dan david Clarke. Application of Measurment to Physical Education. Toronto: W. B. Sauders Company, 1973.

Cook, Anne Shumway dan Marjorie H. Woollacott. Motor Control Theory and Practical Applications. Amerika: Lippincott Williams \& Wilkins, 2001.

Harrow, Anita J. A Taxonomy of The Psycomotor Domain. New York: Longman Inc, 1972.

Hawadi, Reni Akbar. Psikologi Perkembangan Anak, Mengenal Sifat, Bakat dan Kemampuan Anak. Jakarta: Grasindo, 2001.

Luxbacher, Joseph A. Sepakbola Edisi Kedua.Jakarta: PT. Raja Grafindo Persada, 2011.
Magil, Richard A. Motor Learning and Control. New York: Mc Graw Hill, 2011

Mielke, Danny. Dasar-Dasar Sepakbola. Bandung : Pakar Raya, 2007.

Moston, Muska \& Sara Asworth. Teaching Physical Education. New York: Millan College Publishing Company Inc.,1994.

Oxendine, Joseph B. Psychology of Motor Learning. Englewood Cliffs, New Jersey: Prentice, 1984. 